\title{
Deoxyribonucleic Acid Homology Among the Caulobacters
}

\author{
R. L. MOORE, ${ }^{1}$ JEAN SCHMIDT, ${ }^{2}$ JEANNE POINDEXTER, ${ }^{3}$ AND J. T. STALEY ${ }^{4}$ \\ Division of Pathology, Faculty of Medicine, University of Calgary, Calgary, Alberta, Canada T2N 1N4 ${ }^{1}$; \\ Department of Botany and Microbiology, Arizona State University, Tempe, Arizona $85281^{2} ;$ Public Health \\ Research Institute of the City of New York, Inc., New York, New York 10016 ${ }^{3}$; and Department of \\ Microbiology and Immunology, University of Washington, Seattle, Washington $98195^{4}$
}

Deoxyribonucleic acid (DNA) homologies among 26 strains of bacteria including representative type species of the genera Caulobacter, Asticcacaulis, and Prosthecobacter were determined by DNA/DNA reassociation in solution with $\mathrm{S}_{1}$ endonuclease for removing unpaired structures. The relatedness of the strains observed by this procedure are discussed together with previous findings made from numerical taxonomy and phage typing studies.

The caulobacters are single-appendaged prosthecate bacteria represented by the three genera Caulobacter, Asticcacaulis, and Prosthecobacter. The taxonomy of these bacteria has been based upon phenotypic characteristics including morphological and life cycle differences, carbon source utilization patterns, vitamin requirements, colony pigmentation, and so forth. Bacteria in the genus Caulobacter have polar flagella and polar stalks with apical holdfasts, whereas members of the genus Asticcacaulis have subpolar flagella and subpolar prosthecae with basal holdfasts (14). Strains of the recently proposed genus Prosthecobacter resemble Caulobacter species morphologically, but are nonmotile.

The flagellated caulobacters have been classified by numerical taxonomic procedures into 10 species of Caulobacter and 1 species of Asticcacaulis based upon 78 characteristics (14). In addition, a double-appendaged species of Asticcacaulis, $A$. biprosthecum, has been named (13). The fusiform caulobacter is represented by the single species Prosthecobacter fusiformis (18).

A number of phages have been isolated that are effective parasites of motile caulobacters, and these have been used for phage typing studies $(1,14,16)$. Carter and Schmidt (5) recently examined the fatty acid composition of a number of caulobacters and other prosthecate bacteria as a means of comparing relatedness among these organisms.

Although the caulobacters comprise the most thoroughly studied and characterized of the prosthecate bacteria, they also represent the only major family of bacteria in this group yet to be subjected to genotypic comparison using deoxyribonucleic acid (DNA) homology procedures. Both the hyphomicrobia $(10,11)$ and prosthecomicrobia (12) have been the subjects of such studies. Thus, the primary objective of this investigation was to determine the extent of interrelatedness among the caulobacters using DNA hybridization procedures.

\section{MATERIALS AND METHODS}

Bacterial strains. The strains of bacteria utilized in this investigation are listed in Table 1. Except for strains S 3 and C 19, which were kindly provided by Jack Pate, all strains are from the culture collections of the respective authors. The only type species not included in the study were the marine isolates $C$. maris and $C$. halobacteroides.

Each strain was revived from lyophilized or frozen ( $10 \%$ glycerol, -60 or $-70^{\circ} \mathrm{C}$ ) cultures, streaked out, and checked with respect to colonial morphology, and its cell morphology was determined with phase-contrast microscopy.

Growth conditions and DNA labeling. For extraction of unlabeled DNA, Caulobacter and Asticcacaulis strains were grown in PYE medium containing $0.2 \%$ peptone (Difco), $0.1 \%$ yeast extract (Difco), and $1 \%$ vitamin-free Hutner mineral base $(6)$ at $25^{\circ} \mathrm{C}$, with aeration, to the late exponential phase of growth. Prosthecobacter fusiformis strains were grown on MMB medium (19) containing $0.2 \%$ glucose. Each individual culture was observed with phase-contrast photomicroscopy to check for typical morphology and to avoid inclusion of any contaminants. Bacteria were harvested (nonaseptically) by centrifugation. At least one wash with distilled water was employed for each cell preparation. Cell pellets were frozen until the DNA could be extracted.

Type strains of the caulobacters were labeled with $\left[\mathrm{G}^{3} \mathrm{H}\right]$ adenine (New England Nuclear Corp., Boston, Mass.; specific activity, $27.4 \mathrm{Ci} / \mathrm{mmol}$ ). Cultures were grown on a medium containing (per liter): $1 \mathrm{~g}$ of peptone (Difco), $1 \mathrm{~g}$ of glucose, $0.15 \mathrm{~g}$ of yeast extract (Difco), $0.25 \mathrm{~g}$ of ammonium sulfate, $20 \mathrm{ml}$ of a modified Hutner salts solution (20) except that sodium molybdate was included at $19 \mathrm{mg} / \mathrm{liter}$ of stock solution, and $10 \mathrm{ml}$ of a vitamin solution (17). A 100 - to $200-\mathrm{ml}$ volume of logarithmically growing cells was labeled with $1.5 \mathrm{mCi}$ of tritiated adenine early enough in the growth cycle to permit two to three subsequent doublings in optical density. 
TABLE 1. Bacterial strains

\begin{tabular}{|c|c|c|}
\hline Species & Strain no. & Reference and comments \\
\hline Caulobacter crescentus & $\begin{array}{l}\text { CB } 2 \\
\text { CB } 15\end{array}$ & $\begin{array}{r}\text { Type strain, ATCC } 15252 \\
\text { ATCC } 19089\end{array}$ \\
\hline Caulobacter vibrioides & $\begin{array}{l}\text { CB } 51 \\
\text { CB } 16 \\
\text { CB G }\end{array}$ & Neotype strain, C. vibrioides subsp. limonus \\
\hline Caulobacter subvibrioides & CB 88 & $\begin{array}{c}\text { Type strain, ATCC 15265, C. subvibrioides } \\
\text { subsp. albus } \\
\text { ATCC } 15264\end{array}$ \\
\hline Caulobacter fusiformis & CB 27 & Type strain, ATCC 15257 \\
\hline Caulobacter bacteroides & $\begin{array}{l}\text { CB } 7 \\
\text { CB } 11 \text { a } \\
\text { CB } 9 \\
\text { CB } 10\end{array}$ & $\begin{array}{r}\text { Type strain, ATCC } 15254 \\
\text { ATCC } 19090\end{array}$ \\
\hline Caulobacter henricii & $\begin{array}{l}\text { CB } 4 \\
\text { CB R }\end{array}$ & $\begin{array}{l}\text { Type strain, ATCC } 15253 \\
\text { Type strain, ATCC } 15266, \text { C. henricii subsp. } \\
\text { aurantiacus }\end{array}$ \\
\hline Caulobacter leidyi & CB 37 & Type strain, ATCC 15260 \\
\hline Caulobacter variabilis & CB 17 & Type strain, ATCC 15255 \\
\hline Caulobacter intermedius & CB 63 & Type strain, ATCC 15262 \\
\hline Caulobacter sp. type V & CB 28 & Type strain, ATCC 15258 \\
\hline Asticcacaulis excentricus & $\begin{array}{l}\text { AC } 48 \\
\text { AC } 12 \\
\text { S } 3\end{array}$ & Type strain, ATCC 15261 \\
\hline Asticcacaulis biprosthecum & C 19 & Type strain, ATCC 27554 \\
\hline Prosthecobacter fusiformis & $\begin{array}{l}\text { FC } 4 \\
\text { FC } 1 \\
\text { FC } 2 \\
\text { FC } 3\end{array}$ & $\begin{array}{r}\text { Type strain, ATCC } 25309 \\
\text { ATCC } 27091\end{array}$ \\
\hline
\end{tabular}

DNA extraction, purification, and hybridization. DNA was extracted and purified as described previously (12).

Reaction mixtures for DNA/DNA reassociation contained $150 \mu \mathrm{g}$ of heat-dissociated unlabeled and 0.1 $\mu \mathrm{g}$ of labeled DNA in $1.0 \mathrm{ml}$ of $0.17 \mathrm{M} \mathrm{NaCl}$. Reassociation was carried out at $71^{\circ} \mathrm{C}$ for $16 \mathrm{~h}$. Unreacted DNA was hydrolyzed by adding the reaction mixture to $1.0 \mathrm{ml}$ of enzyme solution ( $\mathrm{pH} 4.5$ ) containing 0.2 $\mathrm{mM} \mathrm{ZnSO}_{4}, 0.06 \mathrm{M}$ sodium acetate, $0.17 \mathrm{M} \mathrm{NaCl}, 40$ $\mu \mathrm{g}$ of single-stranded salmon DNA per $\mathrm{ml}$, and sufficient $S_{1}$ endonuclease (Miles Laboratories Inc., Kankakee, Ill.) to hydrolyze $96 \%$ of the single-stranded DNA in $20 \mathrm{~min}$ at $57^{\circ} \mathrm{C}$. Under these conditions, hydrolysis of double-stranded DNA was less than $1 \%$. Reacted DNA was precipitated with trichloroacetic acid and collected by filtration. The radioactivity was measured with a Beckman LS 330 liquid scintillation counter.

\section{RESULTS AND DISCUSSION}

As can be seen from the results (Table 2), there is considerable homology among the strains of $C$. vibrioides and $C$. crescentus. The respective type strains, $\mathrm{CB} 51$ and $\mathrm{CB} 2$, are more closely related by this procedure than are any other strains included in the study. In addition, other strains within these species show a high degree of reassociation with one another. Indeed, using the guidelines proposed for the enteric bacteria by Brenner (3) whereby strains are placed into the same species if they show $70 \%$ or greater DNA homology with one another, one could argue that, with the exception of CB $G$, all of the strains in these two species should be placed in a single species. Bacteriophage host range studies also imply that these two species are very similar $(2,14,16)$. In the numerical taxonomic study (14), CB 2 and CB 51 exhibited a $65 \%$ similarity value $(S)$ to one another. CB 16 had an $S$ of $66 \%$ with CB 51 and $55 \%$ with CB 2, whereas CB 15 showed a $58 \% S$ with CB 51 and $83 \%$ with CB 2. CB G was also more distantly related by the numerical taxonomic study, showing an $S$ of less than $50 \%$ with both type strains.

Although the type strains of $C$. vibrioides and C. crescentus were $97 \%$ homologous to one another, their homologies with CB 15, CB 16, and CB 81 differed by 14,13 , and $19 \%$, respectively. In addition to possible experimental variation, these discrepancies could be due to differences in genome size among these strains (4).

The third frequently isolated vibrioid species of Caulobacter, C. henricii, showed a more distant, but still significant homology with all strains of $C$. vibrioides and $C$. crescentus. This is consistent with the bacteriophage host range studies by Schmidt and Stanier (16) and with the findings of Driggers and Schmidt (8), that 
TABLE 2. DNA homology of caulobacters.

\begin{tabular}{|c|c|c|c|c|c|c|c|c|c|c|c|}
\hline \multirow[b]{2}{*}{ Strain } & \multicolumn{11}{|c|}{ Percent hybridization with DNA from ${ }^{a}$ : } \\
\hline & $\begin{array}{c}\text { Caulobacter } \\
\text { vibrioides CB } \\
51 \\
(7,139)^{b}\end{array}$ & $\begin{array}{c}\text { C. crescen- } \\
\text { tus CB 2 } \\
(18,893)\end{array}$ & $\begin{array}{c}\text { C. henricii } \\
\text { CB 4 } \\
(17,429)\end{array}$ & $\begin{array}{l}\text { C. bacte- } \\
\text { roides CB } 7 \\
\quad(9,248)\end{array}$ & $\begin{array}{c}\text { C. subvi- } \\
\text { brioides } \text { CB } \\
81 \\
(59,500)\end{array}$ & $\begin{array}{l}\text { C. varia- } \\
\text { bilis CB } 17 \\
\quad(58,810)\end{array}$ & $\begin{array}{l}\text { C. interme- } \\
\text { dius } \mathrm{CB} 63 \\
\quad(14,607)\end{array}$ & $\begin{array}{c}\text { C. leidyi CB } \\
37 \\
(5,000)\end{array}$ & $\begin{array}{l}\text { C. fusifor- } \\
\text { mis CB } 27 \\
(42,441)\end{array}$ & $\begin{array}{c}\text { Asticcacaulis } \\
\text { excentricus } \\
\text { AC } 48 \\
(38,840)\end{array}$ & $\begin{array}{c}\text { Prostheco- } \\
\text { bacter fusi- } \\
\text { formis FC } 4 \\
\quad(26,320)\end{array}$ \\
\hline \multicolumn{12}{|l|}{ Caulobacter vibrioides } \\
\hline CB 51 & 100 & (97) & 14 & 6 & 1 & 3 & 2 & (2) & (6) & $(<1)$ & 1 \\
\hline $\mathrm{CB} \mathrm{G}$ & 60 & 58 & 19 & 4 & 2 & 3 & 3 & 3 & $<1$ & $<1$ & 4 \\
\hline CB 16 & 90 & 77 & 34 & $<1$ & 5 & 2 & 4 & 2 & $<1$ & $<1$ & $<1$ \\
\hline \multicolumn{12}{|l|}{ C. crescentus } \\
\hline CB 2 (ATCC 15252) & 97 & $(100)$ & 22 & 6 & 20 & 2 & 3 & 2 & (6) & 1 & $<1$ \\
\hline CB 15 (ATCC 19089) & 85 & 71 & 16 & 2 & 1 & $<1$ & 1 & $<1$ & $<1$ & $<1$ & $<1$ \\
\hline \multirow{2}{*}{\multicolumn{12}{|c|}{ C. henricii }} \\
\hline CB 4 (ATCC 15253) & & & & (9) & (2) & & (2) & $(<1)$ & (2) & & \\
\hline CB R (ATCC 15266) & 2 & 3 & 4 & 6 & 9 & 6 & 33 & 3 & $<1$ & $<1$ & $<1$ \\
\hline \multicolumn{12}{|l|}{ C. bacteroides } \\
\hline CB 7 (ATCC 15254) & 9 & 9 & 100 & 19 & 13 & 15 & (2) & (6) & 3 & 3 & \\
\hline CB 10 & 1 & 2 & $<1$ & 30 & 10 & 7 & 8 & $<1$ & $<1$ & $<1$ & $<1$ \\
\hline CB 9 & 2 & 2 & 3 & 29 & 15 & 8 & 6 & 1 & $<1$ & $<1$ & $<1$ \\
\hline CB 11a (ATCC 19090) & 2 & 2 & $<1$ & 24 & 19 & 8 & 8 & 3 & $<1$ & $<1$ & $<1$ \\
\hline $\begin{array}{l}\text { C. intermedius CB } 63 \\
\text { (ATCC 15262) }\end{array}$ & 2 & 3 & 2 & 11 & (9) & 8 & 100 & $(<1)$ & (3) & $<1$ & $<1$ \\
\hline $\begin{array}{l}\text { C. fusiformis CB } 27 \text { (ATCC } \\
15257 \text { ) }\end{array}$ & 6 & 6 & 2 & 6 & $<1$ & 1 & 3 & 3 & 100 & $<1$ & $<1$ \\
\hline \multicolumn{12}{|l|}{ C. subvibrioides } \\
\hline CB 81 (ATCC 15264) & 1 & $(20)$ & 2 & (19) & 100 & 10 & 9 & $(<1)$ & $(<1)$ & $(<1)$ & $(<1)$ \\
\hline CB 88 (ATCC 15265) & 10 & 1 & 8 & 12 & 12 & $<1$ & 15 & (2) & (6) & 3 & 3 \\
\hline $\begin{array}{l}\text { C. variabilis CB } 17 \text { (ATCC } \\
15255 \text { ) }\end{array}$ & (3) & (2) & 7 & (13) & (10) & 100 & (8) & (4) & (4) & 3 & $(<1)$ \\
\hline $\begin{array}{l}\text { C. leidyi CB } 37 \text { (ATCC } \\
15260)\end{array}$ & 2 & (2) & 4 & 2 & $<1$ & $<1$ & $<1$ & 100 & (3) & $<1$ & 1 \\
\hline $\begin{array}{c}\text { Caulobacter sp. type V CB } \\
\text { 28 (ATCC 15261) }\end{array}$ & $<1$ & $<1$ & $<1$ & 29 & 11 & 9 & 8 & $<1$ & $<1$ & 1 & $<1$ \\
\hline \multicolumn{12}{|l|}{ Asticcacaulis eccentricus } \\
\hline AC 48 (ATCC 15261) & $<1$ & (1) & 2 & (3) & $<1$ & $<1$ & $<1$ & 2 & $(<1)$ & 100 & $<1$ \\
\hline S 3 & $<1$ & $<1$ & $<1$ & $<1$ & $<1$ & 2 & $<1$ & $<1$ & $<1$ & 86 & $<1$ \\
\hline AC 12 & $<1$ & $<1$ & 3 & $<1$ & 1 & $<1$ & $<1$ & 2 & $<1$ & 33 & $<1$ \\
\hline $\begin{array}{l}\text { A. biprosthecum C } 19 \\
\text { (ATCC 127554) }\end{array}$ & - & - & 3 & 0 & - & 5 & 0 & - & 1 & - & 1 \\
\hline \multicolumn{12}{|l|}{ Prosthecobacter fusiformis } \\
\hline FC 4 (ATCC 25309) & (1) & $(<1)$ & $<1$ & (3) & $<1$ & $<1$ & $<1$ & 2 & $(<1)$ & $<1$ & 100 \\
\hline FC 1 (ATCC 27091) & - & - & - & - & - & 9 & - & $<1$ & - & - & 5 \\
\hline FC 2 & - & - & - & - & - & - & - & 3 & - & - & 1 \\
\hline FC 3 & - & - & - & - & - & - & - & $<1$ & - & - & 3 \\
\hline
\end{tabular}

${ }^{a}$ The hybridization values are the average of assays performed in triplicate and have been corrected for background counts obtained with DNA from Prosthecomicrobium enhydrum (7.6\% of input). Eighty percent of the input ${ }^{3} \mathrm{H}$-labeled DNA used in the homologous reactions underwent reassociation. Values listed in parentheses were obtained in the reciprocal reaction and are listed for comparison. - indicates that the analysis was not performed.

${ }^{b}$ Numbers in parentheses in column headings indicate specific activity (in counts per minute per microgram) of tritium-labeled DNA. 
latent bacteriophages isolated from either of the first two vibrioid species were lytic for $C$. henricii strains. Further, in Poindexter's numerical analysis, some strain pairs of $C$. henricii and $C$. vibrioides displayed $S$ values greater than $60 \%$. Interestingly, $C$. henricii $\mathrm{CB} \mathrm{R}$ was very distantly related to the type strain of the species, but showed considerable homology to $C$. intermedius. This is consistent with the numerical taxonomic analysis, in which this strain exhibited $57 \% S$ with the type strain of $C$. henricii and $74 \%$ with the type strain of $C$. intermedius. Strain CB R was originally classified as a subspecies, C. henricii subsp. aurantiacus (14).

The remaining vibrioid species, $C$. intermedius, displayed the widest range of generally low, but possibly significant homologies. This was similar to its intermediate phenotypic position among the isolates used in the numerical analysis.

Accordingly, the vibrioid Caulobacter species appear to consist of two possibly redundant species (C. vibrioides and $C$. crescentus), a third moderately related species ( $C$. henricii), and a fourth (C. intermedius) no more closely related to those three than to nonvibrioid species.

C. bacteroides comprised a group of strains related to the type strain (CB 7) in a relatively distant but consistent pattern. Caulobacter sp. type $\mathrm{V}$ was the most closely related strain outside the group, and by DNA homology was more closely related to this group than to any other. Type V strains were phenotypically similar to $C$. bacteroides, but not so designated by Poindexter because of their equal similarity to C. variabilis. The homologies of $C$. subvibrioides strain CB 81 and $C$. variabilis $\mathrm{CB} 17$ were also greater than $10 \%$ with $C$. bacteroides CB 7 . In addition to showing a significant but low level of homology to CB 7, C. subvibrioides showed a similar degree of homology to other strains in that species as well as to $C$. crescentus $\mathrm{CB} 2$. The phenotypic analysis had revealed similarity between $C$. sub. vibrioides and $C$. variabilis, but not between either of these species and $C$. bacteroides, or between $C$. subvibrioides and C. crescentus (14).

Some type species of Caulobacter, e.g., C. leidyi and C. fusiformis, exhibited little or no homology with any of the other strains studied. Thus, there is strong justification for separate species in these cases.

Correspondingly distant relatedness was shown by the intergeneric DNA hybridizations conducted. For example, although strains of $A s$ ticcacaulis excentricus were 33 and $86 \%$ homologous with the type strain, only low levels of homology $(<3 \%)$ were detected with all other strains of Asticcacaulis as well as strains of Caulobacter and Prosthecobacter. Such low ho- mologies were found even between strains now known to share susceptibility to certain phages (9). A. biprosthecum was not closely related to any of the strains with which it was compared. This is in agreement with bacteriophage host range studies and with unpublished results of DNA homology studies of five Asticcacaulis strains by John Johnson and Jack Pate (personal communication). Similarly, $P$. fusiformis FC 4 exhibited little, if any, homology either to the motile caulobacters or to the other nonmotile strains in this species.

It is of interest to compare the results of taxonomic studies of the caulobacter family with those of the more thoroughly studied family of enteric bacteria. Adansonian analysis of the $E n$ terobacteriaceae indicates that $75 \% S$ or higher comprises a species cluster using 100 or more characteristics (4). The genus level relationship is circumscribed by percent $S$ of between 70 and 75. Although a slightly smaller number of characteristics, 78, has been used in the caulobacter group, the similarity values were markedly lower for this group, running generally greater than only $60 \%$ for the species level and less than $60 \%$ for the genus. With one exception, namely, $C$. crescentus and $C$. vibrioides, the phenotypic criteria for delineating these taxa are consistent with the DNA homology data, indicating that there is greater genetic and phenotypic diversity in a species of the genus Caulobacter and in the genus Caulobacter than in a species and genus in the family of enteric bacteria. This observation is in agreement with the comment of S. T. Cowan (7): " . . . the ranking within the family [Enterobacteriaceae] has come out of register with that of other areas of bacterial classification, so that taxa which in other families are ranked as species, in this family occur as genera or in some cases as tribes." Therefore, although it would a priori seem reasonable that genetic analysis of relatedness might provide a common basis for all bacteria in cricumscribing taxa at the species and genus levels, there are other pragmatic considerations that will determine the practicality of using this approach. The designation of a given level of DNA homology as determinative of a particular taxon will continue to be qualified by considerations of phenotypic similarity, and so can be expected to vary from one bacterial group to another.

\section{ACKNOWLEDGMENTS}

Excellent technical assistance was provided by Robert Bigford and Cara Snider. Our thanks to John Johnson and Jack Pate for showing us unpublished data. This study was in part supported by National Science Foundation Grant DEB7521353 and President's National Research Council of Canada Research Fund 7676. 


\section{REPRINT REQUESTS}

Address reprint requests to: Dr. Richard L. Moore, The University of Calgary, 2920 24th Ave., N.W., Calgary, Canada T2N 1N4.

\section{LTTERATURE CITED}

1. Agabian-Keshishian, N., and L. Shapiro. 1970. Stalked bacteria: properties of deoxyribonucleic acid bacteriophage $\mathrm{Cb}$ K. J. Virol. 5:795-800.

2. Babinchak, J. A., and V. F. Gerencser. 1976. Bacteriophage typing of the "Caulobacter group." Int. J. Syst. Bacteriol. 26:82-84.

3. Brenner, D. J. 1973. Deoxyribonucleic acid reassociation in the taxonomy of enteric bacteria. Int. J. Syst. Bacteriol. 23:298-307.

4. Brenner, D. J., G. R. Fanning, F. J. Skerman, and S. Falkow. 1972. Polynucleotide sequence divergence among strains of Escherichia coli and closely related organisms. J. Bacteriol. 109:953-96.

5. Carter, R. N., and J. M. Schmidt. 1976. Fatty acid composition of selected prosthecate bacteria. Arch. Microbiol. 110:91-94.

6. Cohen-Bazire, G., W. R. Sistrom, and R. Y. Stanier. 1957. Kinetic studies of pigment synthesis by non-sulfur purple bacteria. J. Cell. Comp. Physiol. 49:25-61.

7. Cowan, S. T. 1974. Enterobacteriaceae Rahn 1937, p. 290-293. In R. E. Buchanan and N. E. Gibbons (ed.), Bergey's manual of determinative bacteriology, 8th ed. The Williams and Wilkins Co., Baltimore.

8. Driggers, L. J., and J. M. Schmidt. 1970. Induction of defective and temperate bacteriophages in Caulobacter. J. Gen. Virol. 6:421-427.

9. Middleton, C. A., and J. L. Pate. 1976. Isolation and partial characterization of some bacteriophages active against Asticcacaulis strains. Int. J. Syst. Bacteriol.
26:269-277.

10. Moore, R. L. 1977. Ribosomal ribonucleic acid cistron homologies among Hyphomicrobium and various other bacteria. Can. J. Microbiol. 23:478-481.

11. Moore, R. L., and P. Hirsch. 1972. Deoxyribonucleic acid base sequence homologies of some budding and prosthecate bacteria. J. Bacteriol. 110:256-261.

12. Moore, R. L., and J. T. Staley, 1976. Deoxyribonucleic acid homology of Prosthecomicrobium and Ancalomi. crobium strains. Int. J. Syst. Bacteriol. 26:281-285.

13. Pate, J. L., J. S. Porter, and T. L. Jordan. 1973. Asticcacaulis biprosthecum sp. nov. Life cycle, morphology and cultural characteristics. Antonie van Leeuwenhoek J. Microbiol. Serol. 39:569-583.

14. Poindexter, J. S. 1964. Biological properties and classification of the Caulobacter group. Bacteriol. Rev. 28:231-295.

15. Poindexter, J. S., and R. F. Lewis. 1966. Recommendations for revision of the taxonomic treatment of stalked bacteria. Int. J. Syst. Bacteriol. 16:377-382.

16. Schmidt, J. M., and R. Y. Stanier. 1965. Isolation and characterization of bacteriophages active against stalked bacteria. J. Gen. Microbiol. 39:95-197.

17. Staley, J. T. 1968. Prosthecomicrobium and Ancalomi crobium: new prosthecate freshwater bacteria. J. Bacteriol. 95:1921-1942.

18. Staley, J. T., J. A. M. deBont, and K. de Jonge. 1976. Prosthecobacter fusiformis nov. gen. et sp., the fusiform caulobacter. Antonie van Leeuwenhoek J. Microbiol. Serol. 42:333-342.

19. Staley, J. T., and M. Mandel. 1973. Deoxyribonucleic acid base composition of Prosthecomicrobium and $A n$ calomicrobium strains. Int. J. Syst. Bacteriol. 23:271-273.

20. Van Ert, M., and J. T. Staley. 1971. Gas vacuolated strains of Microcyclus aquaticus. J. Bacteriol. 108:236-240. 